\title{
Results of Fetal Ultrasound Imaging and Doppler Ultrasound Study in Pregnant Women with Extragenital Pathology
}

\author{
Agamurad A. Orazmuradov, $\mathrm{PhD}, \mathrm{ScD}^{1}$; Setonde Romeo D. Konnon, $\mathrm{PhD}^{1}$; \\ Maya T. Khubetsova, $\mathrm{PhD}^{1}$; Anastasia V. Minaeva ${ }^{1}$; Dmitriy S. Novginov ${ }^{1}$; \\ Irina V. Savenkova ${ }^{1}$; Olga L. Paendi, $\mathrm{PhD}^{2}$; Aleksey A. Lukaev, $\mathrm{MD}^{3 *}$ \\ 'Peoples' Friendship University of Russia (RUDN University), Russia \\ ${ }^{2}$ Moscow clinical hospital No.1 named after N. I. Pirogov, Russia \\ ${ }^{3}$ Mytischi City Clinical Hospital, Russia
}

\begin{abstract}
The aim of this research was to study the parameters of fetal ultrasound imaging and Doppler ultrasound study in pregnant women with extragenital diseases (EGDs) during the treatment regimes with and without hyperbaric oxygen therapy (HBOT).

Materials and Methods: A total of 235 pregnant women were examined prospectively at 5 to 40 weeks of gestation. The main group included 191 women with EGDs (anemia, arterial hypertension, chronic pyelonephritis); the control group included 44 women with physiological pregnancy without EGDs. Evaluation of treatment efficacy was based on data from clinical and laboratory findings before treatment and after its completion. The following hardware methods of research were performed: ultrasonography, fetometry, dopplerometric study of fetoplacental complex.

Results: Based on data obtained from this study, the following findings were made:

- In the early stages of gestation, there were no disturbances in fetoplacental blood circulation.

- Starting the 19th week of pregnancy, there is a significant increase in the uterine artery resistive index in pregnant women with arterial hypertension.

- In women with a high perinatal risk on the background of the studied EGDs, the third trimester of pregnancy, despite the ongoing conventional treatment, is characterized by persistent impairment in fetoplacental blood circulation.

- The inclusion of HBOT in complex therapy in the early stages of pregnancy in women with a high perinatal risk allows leveling out the inevitable disturbances in fetoplacental blood circulation on the background of the studied EGDs. (International Journal of Biomedicine. 2018;8(3):206-212.)
\end{abstract}

Key Words: pregnancy $\bullet$ anemia $\bullet$ arterial hypertension $\bullet$ chronic pyelonephritis $\bullet$ hyperbaric oxygen therapy

\section{Abbreviations}

AH, arterial hypertension; BPD, biparietal diameter; CRL, crown-rump length; ChP, chronic pyelonephritis; CT, conventional treatment; EGDs, extragenital diseases; FPC, fetoplacental complex; FL, femur length; HBO, hyperbaric oxygen; HBOT, HBO therapy; IUGR, intrauterine growth retardation; MCA, fetal middle cerebral artery; NT, nuchal translucency; NBL, nasal bone length; PR, perinatal risk; PI, placental insufficiency; PB, premature birth; RCH, retrochorial hematoma; RA, radial artery; RI, resistive index; SA, spiral artery; TAD, transverse abdominal diameter; TCD, transverse cerebellar diameter; UmA, umbilical artery; UtA, uterine artery.

\section{Introduction}

In recent years, extragenital diseases (EGDs) have occupied a leading position $(28 \%)$ in the structure of causes of maternal mortality in developed countries and Russia
$(23 \%)$. $^{(1)}$ The onset and development of pregnancy against the background of such EGDs as anemia, $\mathrm{AH}$, and $\mathrm{ChP}$, occurs in conditions of angiopathy, primarily of the uterus vessels. ${ }^{(2)}$ Angiopathy contributes to the unavoidable development of placental insufficiency during all EGDs. ${ }^{(3)}$ 
Anemia in pregnancy is a major public health and economic problem worldwide and contributes to both maternal and fetal morbidity and mortality. ${ }^{(4-6)}$ Anemia, even in early pregnancy has been associated with adverse pregnancy outcome. $^{(7)}$ Clinical manifestations include fetal growth restriction, preterm delivery, low birth weight, ${ }^{(8)}$ impaired lactation, poor maternal/infant behavioural interactions, post partum depression and increased fetal and neonatal mortality. ${ }^{(5,6)}$

Pyelonephritis in pregnancy confers a high risk of maternal complications and preterm birth. ${ }^{(9)}$ Serious morbidity associated with pyelonephritis in pregnancy is common. Sepsis and septic shock occur secondary to pyelonephritis more frequently than secondary to any other infectious process during pregnancy. ${ }^{(10)}$ Acute respiratory distress syndrome complicates approximately $1-8.5 \%$ of pyelonephritis cases. ${ }^{(11,12)}$

High blood pressure during pregnancy poses various risks, including decreased blood flow to the placenta, placental abruption, intrauterine growth restriction, premature delivery, preeclampsia, and Cesarean delivery.

Since the late 70s, some authors in Russia have tried to treat both acute hypoxia in labor and fetal growth restriction secondary to placental insufficiency with $\mathrm{HBO} .{ }^{(13-15)} \mathrm{HBO}$ has been used for threatened abortion, fetal hypoxia, toxemias of pregnancy, and diabetes in pregnant women. The research found that $\mathrm{HBO}$ was invaluable in improving both placental blood flow and $\mathrm{O}_{2}$ diffusion at the cellular level. ${ }^{(16)} \mathrm{XM}$ Xiao and colleagues reported that HBOT could reduce the values of systolic/diastolic ratio and the pulse index in umbilical arteries of late-onset fetal growth restriction patients, could improve the uteroplacental microcirculation and neonatal birth weight. HBOT is an effective method for the treatment of late-onset fetal growth restriction. ${ }^{(17)}$

The effects of HBO are based on the gas laws, and the physiological and biochemical effects of hyperoxia. HBO has complex effects on immunity, oxygen transport and hemodynamics. The positive therapeutic effects come from a reduction in hypoxia and edema. ${ }^{(18)}$ Infections, injury, and disease increase tissue demands for oxygen while such problems as anemia, toxins and hemorrhage can decrease the body's ability to transport oxygen via hemoglobin. Delivery of $100 \%$ oxygen under pressure allows plasma to carry much more oxygen and reduces the importance of hemoglobinbased delivery. ${ }^{(19)} 100 \%$ oxygen dissolved in plasma can be delivered from capillaries to tissues at least three times farther than delivered when carried by hemoglobin alone. ${ }^{(19,20)}$

When hemoglobin drops to critical levels to disallow proper oxygen delivery, hyperbaric oxygen therapy may be used as bridge therapy to emergently supply oxygen. To address severe anemia in trauma or illness, the future may well afford the use of hyperbaric oxygen therapy in the military far-forward, in pre-hospital EMS settings, in trauma center emergency departments, in operative and recovery units, and in intensive care units of hospitals. ${ }^{(21)}$

HBO has been shown to be a valuable adjunct to the medical and surgical treatment of various infections. Host defense mechanisms against infection are impaired by hypoxia and oxygen has an adjunct effect with antibiotics. ${ }^{(22-24)}$

$\mathrm{HBO}$ restores the bactericidal capacity of leukocytes in hypoxic wounds by increasing tissue oxygen tensions. ${ }^{(25)}$ HBO has been observed to activate many mechanisms, including accelerated macrophage infiltration ${ }^{(26)}$ and improved antibactericidal capacity. ${ }^{(27)}$

Hyperbaric oxygen (HBO) has been found to be useful in the management of various cardiovascular disorders. ${ }^{(28)}$ The effectiveness of HBOT on selected divers suffering hypertension was shown in the pilot study by Minthara Benny. ${ }^{(29)}$ LopezCalderon and colleagues showed that HBO therapy reduced BP and decreased vascular reactivity to angiotensin II in the coronary arteries of hypertensive rats. These changes were associated with a decrease in the expression of AT1Rs. ${ }^{(30)}$

The value of hyperbaric oxygen is now well appreciated in human medicine and accepted as treatment for many indications. $^{(31)} \mathrm{HBO}$ has shown a therapeutic effect when used for various pathologies. ${ }^{(28)}$ The use of HBO during pregnancy has been shown to be safe. ${ }^{(32-35)}$

The aim of this research was to study the parameters of fetal ultrasound imaging and Doppler ultrasound study in pregnant women with EGDs during the treatment regimes with and without HBOT.

\section{Materials and Methods}

The study was performed in Municipal clinical hospital №29 named after N.E. Bauman (clinical base of RUDN University). The study was conducted in accordance with ethical principles of the Declaration of Helsinki.

A total of 235 pregnant women were examined prospectively at 5 to 40 weeks of gestation. Depending on the presence of EGDs, the women were divided into 2 groups. The main group included 191 women with EGDs; the control group included 44 women with physiological pregnancy without EGDs.

Depending on the nature of EGDs, the main group was divided into three groups: Group 1 comprised 88 pregnant women with anemia (code ICD-X: O99.0 - anemia complicating pregnancy, childbirth and the puerperium), Group 2 comprised 50 pregnant women with AH (code ICD-X: O10 - pre-existing hypertension complicating pregnancy, childbirth and the puerperium), and Group 3 comprised 53 pregnant women with ChP (code ICD-X: O23.0 - kidney infection in pregnancy). In turn, the three groups were divided into subgroups, depending on the nature of the therapy: conventional treatment $(\mathrm{CT})$ or $\mathrm{CT}+\mathrm{HBOT}$. All examined women with EGD belonged to a group with high perinatal risk (PR). We identified the degree of PR based on the scale developed by O.G. Frolova and E.I. Nikolaeva (1981) and modified in by V.E. Radzinsky et al.(2003). According to this modified scale, there is three level of PR: low risk (<15points), moderate risk (from 15 to 20 points), and high risk ( $\geq 25$ points).

Inclusion criteria were singleton pregnancy, high PR, and voluntary informed consent to HBOT.

Exclusion criteria were cancer, multiple pregnancies, signs of placental abruption and the contraindications to the use of HBOT (an untreated pneumothorax (absolute contraindication) and relative contraindications (a history of epilepsy, viral infectios, pacemaker, claustrophobia, etc.). 
Evaluation of treatment efficacy was based on data from clinical and laboratory findings before treatment and after its completion. The following hardware methods of research were performed: ultrasonography, fetometry, dopplerometric study of fetoplacental complex.

Ninety-eight women of the main group received the HBOT sessions (excess air pressure 1.3-1.5 atm in a pressure chamber) in addition to CT. We used Monoplace Hyperbaric Oxygen Therapy Chamber BLKS-307-«Khrunichev» (Russia), equipped with air-conditioning 54-58A and designed to conduct sessions in a high-pressure oxygen environment. The mode is one excess atmosphere. ${ }^{(36)}$ The course includes 5-7 daily sessions lasting 40 minutes each. The first course was carried out in 6-9 weeks, the second in 16-18 weeks, and the third in 24-28 weeks of pregnancy.

Statistical analysis was performed using the Statistica 8.0 software package (StatSoft Inc, USA). Baseline characteristics were summarized as frequencies and percentages for categorical variables. Continuous variables were presented as mean $(\mathrm{M}) \pm$ standard error of the mean (SEM). T test was used for comparison between two groups with a normal distribution of the quantitative characteristic. Mann-Whitney $\mathrm{U}$ test and Kruskal-Wallis test were used, respectively, to compare means of 2 and 3 or more groups of variables not normally distributed. Group comparisons with respect to categorical variables are performed using chisquare tests. Multiple comparisons were performed with one-way ANOVA and post-hoc Tukey HSD test. A probability value of $P<0.05$ was considered statistically significant.

\section{Results and Discussion}

The analysis of ultrasound data in the first trimester in patients with a high PR revealed no significant differences in the main fetometric parameters (CRL, NT, NBL) depending on EGDs. However, a number of characteristic changes were detected during the ultrasound scanning (Table 1).
$\mathrm{RCH}$ was not found in the control group compared to the main group, except for the CT+HBOT subgroups. Thus, in pregnant women with $\mathrm{AH}, \mathrm{RCH}$ was detected significantly more often $(P<0.05)$ compared to those with anemia and $\mathrm{ChP}(24 \%$ vs. $14.3 \%$ and $15.4 \%$, respectively). Ultrasonic signs of chorionitis were diagnosed significantly more often in Group 3 (30.8\%), while this symptom was not detected in the control group and Group $2(P<0.05)$. Pregnant women of Group 1 showed signs of chorionitis in $5.7 \%$ of cases; there were no significant differences between subgroups. Reduction of amniotic fluid volume and fetal egg size was diagnosed in two (4.5\%) women of the control group, whereas this symptom was significantly more frequent $(P<0.05)$ in the main group (Table 1$)$.

Reduced fetal egg size and changes in the yolk sac (cystic changes, decrease in size) were detected more often $(P<0.05)$ in women of the main group. In Group 1, this symptom was diagnosed in $29.5 \%$ of cases, which was significantly more often compared to the control group and Groups 3 and 2 (4.5\%, $13.2 \%$ and $20 \%$, respectively).

\section{Fetometry data}

Fetometry in 20-22 gestational weeks showed a statistically significant decrease $(P<0.05)$ in $\mathrm{BPD}$, TAD and FL in Group 1 against the background of $\mathrm{CT}$ in comparison with $\mathrm{CT}+\mathrm{HBOT}$ and the control group (Table 2). In other subgroups, no significant differences were found. However, there was a tendency to increased sizes of BPD, TAD, FL and TCD in the $\mathrm{CT}+\mathrm{HBOT}$ subgroups compared to the $\mathrm{CT}$ subgroups.

Thus, it can be assumed that a decrease in the size of BPD, TAD and FL in the period of 20-22 weeks of gestation in the group of women with anemia who received CT is the most important reason for justifying the timing for HBOT.

We found significant differences in a number of analyzed fetometric parameters in 29-32 gestational weeks (Table 3). Significant decreases $(P<0.05)$ in BPD, TAD and FL were found in all pregnant women with a high PR against the background of EGDs in comparison with the control group.

Table 1.

Ultrasonic data in the first trimester of pregnancy

\begin{tabular}{|c|c|c|c|c|c|c|}
\hline \multicolumn{3}{|c|}{ Patient Groups } & $\mathrm{RCH}$ & Chorionitis & RAFV + RFES & $\begin{array}{l}\text { RFES and changes } \\
\text { in the yolk sac }\end{array}$ \\
\hline \multirow{6}{*}{  } & \multirow{2}{*}{ Group 1} & $\mathrm{CT}(\mathrm{n}=42)$ & $\begin{array}{l}6(14.3 \%) \\
* P=0.0431\end{array}$ & $2(4.8 \%)$ & $\begin{array}{l}11(26.2 \%) \\
* P=0.0048\end{array}$ & $\begin{array}{l}13(30.9 \%) \\
* P=0.0011\end{array}$ \\
\hline & & $\begin{array}{l}\mathrm{CT}+\mathrm{HBOT} \\
(\mathrm{n}=46)\end{array}$ & 0 & $3(6.5 \%)$ & $\begin{array}{l}11(23.9 \%) \\
* P=0.0048\end{array}$ & $\begin{array}{l}13(28.3 \%) \\
* P=0.0011\end{array}$ \\
\hline & \multirow{2}{*}{ Group 2} & $\mathrm{CT}(\mathrm{n}=25)$ & $\begin{array}{c}6(24.0 \%) \\
* P=0.0165 \\
* * P=0.0385\end{array}$ & 0 & $\begin{array}{c}5(20.0 \%) \\
* P=0.0766\end{array}$ & $\begin{array}{c}5(20.0 \%) \\
* P=0.0766\end{array}$ \\
\hline & & $\begin{array}{l}\mathrm{CT}+\mathrm{HBOT} \\
(\mathrm{n}=25)\end{array}$ & 0 & 0 & $\begin{array}{c}5(20.0 \%) \\
* P=0.0766\end{array}$ & $\begin{array}{c}5(20.0 \%) \\
* P=0.0766\end{array}$ \\
\hline & \multirow{2}{*}{ Group 3} & $\mathrm{CT}(\mathrm{n}=26)$ & $\begin{array}{c}4(15.4 \%) \\
* P=0.0819\end{array}$ & $\begin{array}{l}8(30.8 \%) \\
* P=0.0155\end{array}$ & $\begin{array}{l}9(34.6 \%) \\
* P=0.008\end{array}$ & $4(15.4 \%)$ \\
\hline & & $\begin{array}{l}\mathrm{CT}+\mathrm{HBOT} \\
(\mathrm{n}=27)\end{array}$ & 0 & $\begin{array}{c}9(33.3 \%) \\
* P=0.01\end{array}$ & $\begin{array}{c}9(33.3 \%) \\
* P=0.01\end{array}$ & $3(11.1 \%)$ \\
\hline \multicolumn{3}{|c|}{ Control group $(n=44)$} & 0 & 0 & $2(4.5 \%)$ & $2(4.5 \%)$ \\
\hline \multicolumn{3}{|c|}{ Total $(n=235)$} & $16(6.8 \%)$ & $22(9.3 \%)$ & $52(22.1 \%)$ & $45(19.1 \%)$ \\
\hline
\end{tabular}

RAFV - reduced amniotic fluid volume; RFES- reduced fetal egg size *- statistically significant differences between the subgroup and control group; **- statistically significant differences between two subgroups 
However, in the $\mathrm{CT}+\mathrm{HBOT}$ subgroups, the values of $\mathrm{BPD}$, TAD and FL were significantly greater $(P<0.05)$ compared to the CT subgroups.

Table 2.

Fetometry data in 20-22 gestational weeks, $\mathrm{mm}$

\begin{tabular}{|c|c|c|c|c|c|c|}
\hline \multicolumn{3}{|c|}{ Patient Groups } & BPD & TAD & FL & TCD \\
\hline \multirow{6}{*}{  } & \multirow{2}{*}{ 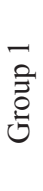 } & $\begin{array}{l}\mathrm{CT} \\
(\mathrm{n}=42)\end{array}$ & $\begin{array}{c}50.6 \pm 0.8 \\
* P<0.001 \\
* * P<0.001\end{array}$ & $\begin{array}{c}47.3 \pm 0.9 \\
* P<0.001 \\
* * P<0.001\end{array}$ & $\begin{array}{c}37.3 \pm 0.9 \\
* P<0.001 \\
* * P=0.004\end{array}$ & $\begin{array}{c}21.8+0.4 \\
* P<0.001 \\
* * P=0.013\end{array}$ \\
\hline & & & $\begin{array}{c}52.2+0.7 \\
* P=0.086\end{array}$ & $\begin{array}{l}49.9 \pm 0.4 \\
* P=0.031\end{array}$ & $39.3 \pm 0.8$ & $\begin{array}{c}22.4+0.4 \\
* P=0.093\end{array}$ \\
\hline & \multirow{2}{*}{ 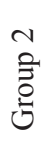 } & $\begin{array}{l}\mathrm{CT} \\
(\mathrm{n}=25)\end{array}$ & $\begin{array}{c}51.6 \pm 0.9 \\
* \mathrm{P}=0.046\end{array}$ & $\begin{array}{l}49.3 \pm 0.9 \\
* P=0.056\end{array}$ & $\begin{array}{l}38.3+0.7 \\
* P=0.021\end{array}$ & $\begin{array}{l}22.1+0.3 \\
* P=0.038\end{array}$ \\
\hline & & $\begin{array}{l}\mathrm{CT}+\mathrm{H} \\
(\mathrm{n}=25\end{array}$ & $53.0 \pm 0.5$ & $51.0 \pm 0.6$ & $39.4+0.5$ & $22.8 \pm 0.3$ \\
\hline & \multirow{2}{*}{ 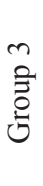 } & $\begin{array}{l}\text { CT } \\
(n=26)\end{array}$ & $\begin{array}{l}50.7+0.8 \\
* P=0.002\end{array}$ & $\begin{array}{c}47.3 \pm 0.9 \\
* P<0.001 \\
* * P=0.046\end{array}$ & $\begin{array}{l}37.6+0.8 \\
* P=0.005\end{array}$ & $\begin{array}{l}22.0+0.5 \\
* P=0.027\end{array}$ \\
\hline & & $\begin{array}{l}\mathrm{CT}+\mathrm{HBOT} \\
(\mathrm{n}=27)\end{array}$ & $51.7 \pm 0.8$ & $50.3+0.5$ & $\begin{array}{l}38.9 \pm 0.9 \\
* P=0.032\end{array}$ & $23.0 \pm 0.3$ \\
\hline \multicolumn{3}{|c|}{$\begin{array}{l}\text { Control group } \\
(\mathrm{n}=44)\end{array}$} & $53.6 \pm 0.4$ & $51.3+0.5$ & $40.1 \pm 0.3$ & $23.6 \pm 0.3$ \\
\hline \multicolumn{3}{|c|}{ Total $(n=235)$} & $51.9 \pm 0.7$ & $49.4 \pm 1.8$ & $38.7 \pm 0.7$ & $22.5 \pm 0.3$ \\
\hline
\end{tabular}

*-statistically significant differences between the subgroup and control group; **-statistically significant differences between two subgroups

Table 3.

Fetometry data in 29-32 gestational weeks, $\mathrm{mm}$

\begin{tabular}{|c|c|c|c|c|c|c|}
\hline \multicolumn{3}{|c|}{ Patient Groups } & $\mathrm{BPD}$ & TAD & $\mathrm{FL}$ & TCD \\
\hline \multirow{6}{*}{ 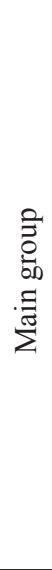 } & \multirow{2}{*}{$\begin{array}{l}\overrightarrow{0} \\
\stackrel{0}{0} \\
\stackrel{0}{0}\end{array}$} & $\begin{array}{l}\mathrm{CT} \\
(\mathrm{n}=42)\end{array}$ & $\begin{array}{c}69.3 \pm 0.9 \\
* P<0.001 \\
* * P<0.001\end{array}$ & $\begin{array}{c}72.3 \pm 0.9 \\
* P<0.001 \\
* * P<0.001\end{array}$ & $\begin{array}{c}51.1 \pm 0.4 \\
* P<0.001 \\
* * P<0.001\end{array}$ & $\begin{array}{c}32.3 \pm 0.7 \\
* P<0.001 \\
* * P<0.001\end{array}$ \\
\hline & & $\begin{array}{r}\mathrm{CT}+\mathrm{H} \\
(\mathrm{n}=4\end{array}$ & $\begin{array}{r}75.3 \pm 0.6 \\
* P<0.001\end{array}$ & $\begin{array}{l}80.9 \pm 0.4 \\
* P<0.001\end{array}$ & $\begin{array}{l}56.6 \pm 0.5 \\
* P<0.001\end{array}$ & $\begin{array}{l}35.5+ \\
* P=0\end{array}$ \\
\hline & \multirow{2}{*}{ 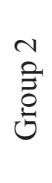 } & $\begin{array}{l}\text { CT } \\
(n=25)\end{array}$ & $\begin{array}{c}72.3+0.7 \\
* P<0.001 \\
* * P<0.001\end{array}$ & $\begin{array}{c}80.3+0.8 \\
* P<0.001 \\
* * P<0.001\end{array}$ & $\begin{array}{c}50.9 \pm 0.4 \\
* P<0.001 \\
* * P<0.001\end{array}$ & $\begin{array}{c}36.0 \pm 0.7 \\
* * P=0.006\end{array}$ \\
\hline & & $\begin{array}{l}\mathrm{CT}+\mathrm{HBOT} \\
(\mathrm{n}=25)\end{array}$ & $\begin{array}{l}77.4 \pm 0.8 \\
* P=0.003\end{array}$ & $84.0 \pm 0.6$ & $\begin{array}{l}57.6 \pm 0.4 \\
* P=0.037\end{array}$ & $38.0 \pm 0.3$ \\
\hline & \multirow{2}{*}{ 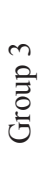 } & $\begin{array}{l}\text { CT } \\
(n=26)\end{array}$ & $\begin{array}{c}68.9 \pm 0.9 \\
* P<0.001 \\
* * P<0.001\end{array}$ & $\begin{array}{c}73.3 \pm 0.9 \\
* P<0.001 \\
* * P<0.001\end{array}$ & $\begin{array}{c}51.9 \pm 0.5 \\
* P<0.001 \\
* * P<0.001\end{array}$ & $\begin{array}{c}33.0 \pm 0.8 \\
* P<0.001 \\
* * P<0.001\end{array}$ \\
\hline & & $\begin{array}{l}\mathrm{CT}+\mathrm{HBOT} \\
(\mathrm{n}=27)\end{array}$ & $\begin{array}{c}76.2 \pm 0.8 \\
* P=0.029\end{array}$ & $\begin{array}{l}79.5 \pm 0.5 * \\
* P<0.001\end{array}$ & $\begin{array}{c}57.0 \pm 0.4 \\
* P=0.005\end{array}$ & $36.1 \pm 0.7$ \\
\hline \multicolumn{3}{|c|}{$\begin{array}{l}\text { Control group } \\
(\mathrm{n}=44)\end{array}$} & $79.5 \pm 0.3$ & $85.3 \pm 0.3$ & $60.0 \pm 0.2$ & $37.3 \pm 0.2$ \\
\hline \multicolumn{3}{|c|}{ Total $(n=235)$} & $74.1 \pm 0.7$ & $79.3 \pm 0.6$ & $55.0 \pm 0.4$ & $35.4 \pm 0.5$ \\
\hline
\end{tabular}

*-statistically significant differences between the subgroup and control group; **-statistically significant differences between two subgroups

The lagged size of TCD was found in the CT subgroups of Groups 1 and 3, while in the CT+HBOT subgroups, TCD did not differ significantly from the control group.

According to the data of fetometry, IUGR was detected in all women of the main group with a high PR (Table 4).
Table 4.

IUGR frequency in pregnant women with a high PR

\begin{tabular}{|c|c|c|c|c|c|c|}
\hline \multicolumn{3}{|c|}{ Patient Groups } & \multicolumn{3}{|c|}{ IUGR, degree } & \multirow{2}{*}{ Total } \\
\hline & & & I & II & III & \\
\hline \multirow{6}{*}{ 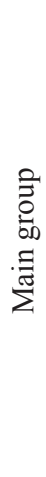 } & \multirow{2}{*}{ 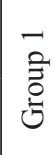 } & $\begin{array}{l}\text { CT } \\
(n=42)\end{array}$ & $\begin{array}{l}8(19.0 \%) \\
* P=0.036\end{array}$ & $3(7.1 \%)$ & 0 & $\begin{array}{c}11(26.2 \%) \\
* P=0.048\end{array}$ \\
\hline & & $\begin{array}{l}\mathrm{CT}+\mathrm{HBOT} \\
(\mathrm{n}=46)\end{array}$ & $6(13.0 \%)$ & 0 & 0 & $6(13.0 \%)$ \\
\hline & \multirow{2}{*}{  } & $\mathrm{CT}(\mathrm{n}=25)$ & $3(12.0 \%)$ & $2(8.0 \%)$ & 0 & $\begin{array}{l}5(20.0 \%) \\
* P=0.076\end{array}$ \\
\hline & & $\begin{array}{l}\mathrm{CT}+\mathrm{HBOT} \\
(\mathrm{n}=25)\end{array}$ & $3(12.0 \%)$ & 0 & 0 & $3(12.0 \%)$ \\
\hline & \multirow{2}{*}{ 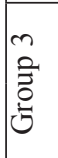 } & $\mathrm{CT}(\mathrm{n}=26)$ & $3(11.5 \%)$ & $2(7.7 \%)$ & 0 & $\begin{array}{l}5(19.2 \%) \\
* P=0.083\end{array}$ \\
\hline & & $\begin{array}{l}\mathrm{CT}+\mathrm{HBOT} \\
(\mathrm{n}=27)\end{array}$ & $3(11.1 \%)$ & 0 & 0 & $3(11.1 \%)$ \\
\hline \multicolumn{3}{|c|}{$\begin{array}{l}\text { Control group } \\
(\mathrm{n}=44)\end{array}$} & $2(4.5 \%)$ & 0 & 0 & $2(4.5 \%)$ \\
\hline \multicolumn{3}{|c|}{ Total $(n=235)$} & $25(10.6 \%)$ & $7(2.9 \%)$ & 0 & $36(15.3 \%)$ \\
\hline
\end{tabular}

*- statistically significant differences between the subgroup and control group; **- statistically significant differences between two subgroups

In the control group, IUGR (only degree I) was diagnosed only in $4.5 \%$. At the same time, the total frequency of IUGR was significantly higher in the CT subgroups compared to the $\mathrm{CT}+\mathrm{HBOT}$ subgroups ( $>2.0$-fold increase). In addition, in the $\mathrm{CT}+\mathrm{HBOT}$ subgroup of Group 1, we found IUGR of degree I compared to degree I and II (7.1\%) in the CT subgroup. Similar features were observed in subgroups of Group 3. The inclusion of HBOT in complex therapy in Group 2 contributed to a significant decrease $(P<0.05)$ in IUGR frequency (a 1.7fold decrease) in the $\mathrm{CT}+\mathrm{HBOT}$ subgroup.

\section{Dopplerometric study of FPC}

The leading pathogenetic mechanism for the formation of primary PI in women with EGDs is hemodynamic disturbances in the vascular bed of the uterus. Hemodynamic disorders occurring in the placenta originate in the early gestation period and are aggravated with different EGDs. Abnormal uterine artery Doppler findings have shown a significant correlation with the risk of adverse perinatal outcomes such as small for gestational age and admission to Neonatal Intensive Care Units (NICU). ${ }^{(3)}$ Zemel et al., has demonstrated that changes occur in the maternal circulation as early as the first trimester in women who develop pre-eclampsia and IUGR. ${ }^{(5)}$

A Doppler blood flow study in 6-9 gestational weeks did not reveal significant differences in RI of the uterine, radial and spiral arteries (Table 5) depending on the nature of EGDs and the therapy mode. In addition, there were no significant differences between the main group and the control group.

Doppler assessment of blood flow in UtA and UmA in 19-22 gestational weeks showed (Table 6) that, in general, in pregnant women with anemia and $\mathrm{ChP}$, regardless of the nature of the therapy mode, RI of UtA and UmA did not differ significantly from the values of the control group. Significant changes were observed in women with $\mathrm{AH}$ : a significant increase in RI of UtA in the CT subgroup was found in 
comparison with the $\mathrm{CT}+\mathrm{HBOT}$ subgroup, the control group, and Groups 1 and 3, regardless of the mode of therapy.

Table 5.

A Doppler blood flow study in pregnant women with a high PR (6-9 gestational weeks)

\begin{tabular}{|c|c|c|c|c|c|}
\hline & \multirow{2}{*}{\multicolumn{2}{|c|}{ Patient Groups }} & \multicolumn{3}{|c|}{ RI } \\
\hline & & & \multirow{2}{*}{$\frac{\text { UtA }}{0.66 \pm 0.003}$} & \multirow{2}{*}{$\frac{\mathrm{RA}}{0.66 \pm 0.004}$} & \multirow{2}{*}{$\begin{array}{c}\text { SA } \\
0.51 \pm 0.006 \\
* P=0.018\end{array}$} \\
\hline \multirow{6}{*}{ 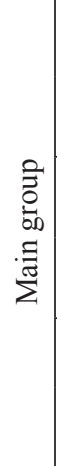 } & \multirow{2}{*}{ Group 1} & $\mathrm{CT}(\mathrm{n}=42)$ & & & \\
\hline & & $\begin{array}{l}\mathrm{CT}+\mathrm{HBOT} \\
(\mathrm{n}=46)\end{array}$ & $0.68 \pm 0.004$ & $0.66 \pm 0.004$ & $0.52 \pm 0.007$ \\
\hline & \multirow{2}{*}{ Group 2} & $\mathrm{CT}(\mathrm{n}=25)$ & $\begin{array}{c}0.71 \pm 0.004 \\
* P<0.001\end{array}$ & $\begin{array}{c}0.69 \pm 0.004 \\
* P=0.002\end{array}$ & $0.55 \pm 0.007$ \\
\hline & & $\begin{array}{l}\mathrm{CT}+\mathrm{HBOT} \\
\mathrm{n}=25)\end{array}$ & $0.69 \pm 0.004$ & $0.67 \pm 0.004$ & $\begin{array}{l}0.56 \pm 0.007 \\
* P=0.004\end{array}$ \\
\hline & \multirow{2}{*}{ Group 3} & $\mathrm{CT}(\mathrm{n}=26)$ & $0.67 \pm 0.002$ & $0.65 \pm 0.009$ & $0.54 \pm 0.006$ \\
\hline & & $\begin{array}{l}\mathrm{CT}+\mathrm{HBOT} \\
(\mathrm{n}=27)\end{array}$ & $0.68 \pm 0.004$ & $0.66 \pm 0.004$ & $0.54 \pm 0.007$ \\
\hline \multicolumn{3}{|c|}{ Control group $(n=44)$} & $0.68 \pm 0.004$ & $0.66 \pm 0.004$ & $0.54 \pm 0.007$ \\
\hline \multicolumn{3}{|c|}{ Total $(n=235)$} & $0.66 \pm 0.003$ & $0.66 \pm 0.004$ & $0.53 \pm 0.006$ \\
\hline
\end{tabular}

*- statistically significant differences between the subgroup and control group

Table 6.

Doppler assessment of blood flow in UtA and UmA in 19-22 gestational weeks

\begin{tabular}{|c|c|c|c|c|}
\hline \multirow{2}{*}{ Patient Groups } & \multirow{2}{*}{\multicolumn{2}{|c|}{ Patient Groups }} & \multicolumn{2}{|c|}{ RI } \\
\hline & & & UtA & UmA \\
\hline \multirow{6}{*}{ 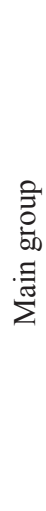 } & \multirow{2}{*}{ Group 1} & $\mathrm{CT}(\mathrm{n}=42)$ & $0.54 \pm 0.003$ & $\begin{array}{l}0.78 \pm 0.005 \\
* P=0.014\end{array}$ \\
\hline & & $\begin{array}{l}\mathrm{CT}+\mathrm{HBOT} \\
(\mathrm{n}=46)\end{array}$ & $0.50 \pm 0.004$ & $0.75 \pm 0.005$ \\
\hline & \multirow{2}{*}{ Group 2} & $\mathrm{CT}(\mathrm{n}=25)$ & $\begin{array}{c}0.67 \pm 0.004 \\
* P<0.001 \\
* * P<0.001\end{array}$ & $\begin{array}{l}0.78 \pm 0.003 \\
* P=0.007\end{array}$ \\
\hline & & $\begin{array}{l}\text { CT+HBOT } \\
(\mathrm{n}=25)\end{array}$ & $0.54 \pm 0.002$ & $0.76 \pm 0.004$ \\
\hline & \multirow{2}{*}{ Group 3} & $\mathrm{CT}(\mathrm{n}=26)$ & $0.53 \pm 0.002$ & $\begin{array}{l}0.70 \pm 0.006 \\
* P=0.007\end{array}$ \\
\hline & & $\begin{array}{l}\text { CT+HBOT } \\
(n=27)\end{array}$ & $0.52 \pm 0.004$ & $0.73 \pm 0.004$ \\
\hline \multicolumn{3}{|c|}{ Control group $(n=44)$} & $0.52 \pm 0.004$ & $0.74 \pm 0.004$ \\
\hline \multicolumn{3}{|c|}{ Total $(n=235)$} & $0.64 \pm 0.003$ & $0.73 \pm 0.005$ \\
\hline
\end{tabular}

*- statistically significant differences between the subgroup and control group; **-statistically significant differences between two subgroups

Changes in maternal-fetal circulation in 29-32 gestational weeks are shown in Table 7. In Group 1, a significant decrease in RI of UtA was detected in the CT subgroup, whereas in the $\mathrm{CT}+\mathrm{HBOT}$ subgroup this indicator did not differ from the control values. In the CT subgroup, against a background of reduced RI of UtA, we found a significant increase $(P<0.05)$ in
RI of UmA and MCA compared to the control group and Group 3. At the same time, in the $\mathrm{CT}+\mathrm{HBOT}$ subgroup, we found normalization in RI of MCA during 29-32 gestational weeks.

In Group 3, there were no significant blood-flow disturbances in MCA, but a significant increase in RI of UtA and UmA in the CT subgroup was diagnosed compared to the control group and the CT+HBOT subgroup.

Table 7.

Doppler assessment of maternal-fetal circulation in 29-32 gestational weeks

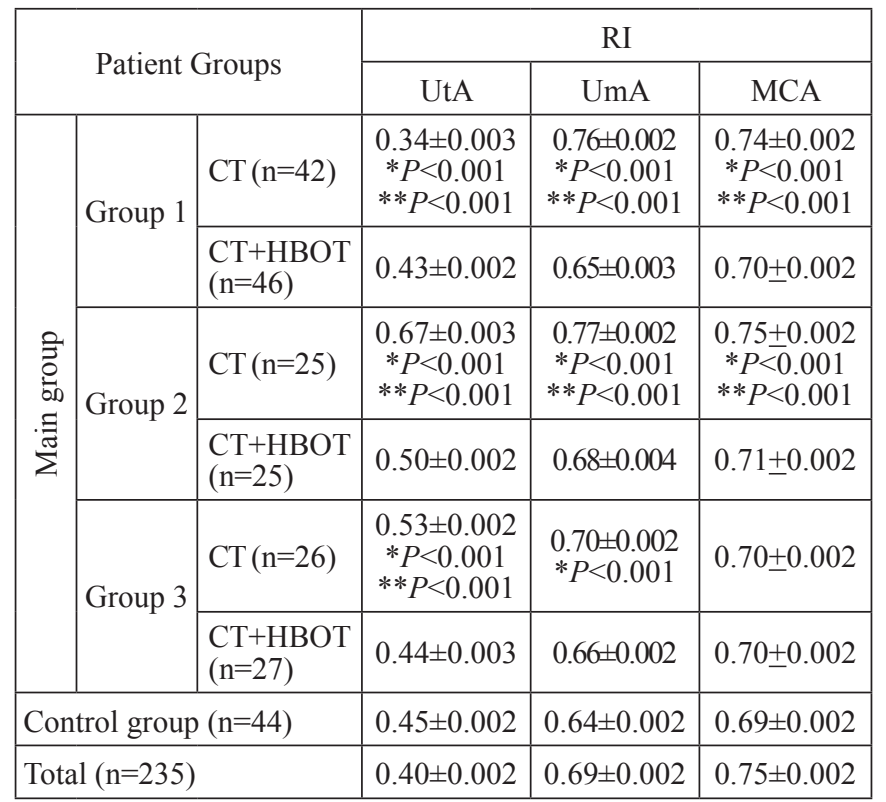

*- statistically significant differences between the subgroup and control group; **- statistically significant differences between two subgroups

In Group 2, a significant increase in RI of UtA, UmA and MCA was diagnosed in the ST subgroup $(P<0.05)$. At the same time, in the $\mathrm{CT}+\mathrm{HBOT}$ subgroup, we found normalization of maternal-fetal circulation, although the tendency for an increase in RI was traced.

In conclusion, HBOT in complex therapy in women with a high PR contributed to a significant decrease in IUGR frequency. In all patients of the CT+HBOT subgroups, we found IUGR only of degree I compared to degrees I (12\%) and II $(8 \%)$ in the CT subgroups. Thus, HBOT in complex therapy allows improving the function of FPC and reducing the incidence of PI in pregnant women with a high PR against the background of EGDs.

Analysis of ultrasound changes in the first trimester of pregnancy showed that such signs as "reduced fetal egg size" and "changes in the yolk sac" in the early stages of gestation are highly correlated with IUGR $(\mathrm{r}=0.67, P<0.01)$. Out of 26 women with anemia and with reduced fetal egg size and changes in the yolk sac, IUGR was diagnosed in $65.3 \%$, in $7(77.8 \%)$ out of 9 women with ChP, and in $8(80 \%)$ out of 10 women with AH. Thus, ultrasound examination of women with EGDs in early stages of pregnancy allows identifying a high-risk group for premature birth. 
Based on the data presented, we can conclude the following:

- In the early stages of gestation, there were no disturbances in fetoplacental blood circulation.

- Starting the 19th week of pregnancy, there is a significant increase in RI of UtA in pregnant women with $\mathrm{AH}$.

- In women with a high PR on the background of the studied EGDs, the third trimester of pregnancy, despite the ongoing CT, is characterized by persistent impairment in fetoplacental blood circulation.

- The inclusion of HBOT in complex therapy in the early stages of pregnancy in women with a high PR allows leveling out the inevitable disturbances in fetoplacental blood circulation on the background of the studied EGDs.

\section{Competing interests} interests.

The authors declare that they have no competing

\section{Acknowledgments}

The publication was prepared with the support of the "RUDN University Program 5-100."

\section{References}

1. Federal State Statistics Service. Rosstat. [Electronic resource]. http:// www.gks.ru (Reference date: September 15, 2015).

2. In Radzinsky VE, Orazmuradov AA, editors. Early gestational age. 2nd ed., rev. version. - M.: StatusPraesens; 2009. [In Russian].

3. Radzinsky VE. Obstetric aggression. M.: StatusPraesens; 2011. [In Russian].

4. Masukume G, Khashan AS, Kenny LC, Baker PN, Nelson G; SCOPE Consortium. Risk factors and birth outcomes of anaemia in early pregnancy in a nulliparous cohort. PLoS One. 2015;10(4):e0122729. doi: 10.1371/journal.pone.0122729.

5. Lee AI, Okam MM. Anaemia in pregnancy. Hematol Oncol Clin North Am. 2011;25(2):241-59, vii. doi: 10.1016/j. hoc.2011.02.001.

6. Goonewardene M, Shehata M, Hamad A. Anaemia in pregnancy. Best Pract Res Clin Obstet Gynaecol. 2012;26(1):324. doi: 10.1016/j.bpobgyn.2011.10.010.

7. Haider BA, Olofin I, Wang M, Spiegelman D, Ezzati M, Fawzi WW; Nutrition Impact Model Study Group (anaemia). Anaemia, prenatal iron use, and risk of adverse pregnancy outcomes: systematic review and meta-analysis. BMJ. 2013;346:f3443. doi: 10.1136/bmj.f3443.

8. Levy A, Fraser D, Katz M, Mazor M, Sheiner E. Maternal anaemia during pregnancy is an independent risk factor for low birthweight and preterm delivery. Eur J Obstet Gynecol Reprod Biol. 2005;122(2):182-6.

9. Dotters-Katz SK, Heine RP, Grotegut CA. Medical and infectious complications associated with pyelonephritis among pregnant women at delivery. Infect Dis Obstet Gynecol. 2013;2013:124102. doi: 10.1155/2013/124102.

10. Snyder CC, Barton JR, Habli M, Sibai BM. Severe sepsis and septic shock in pregnancy: indications for delivery and maternal and perinatal outcomes. J Matern Fetal Neonatal Med. 2013;26(5):503-6. doi: 10.3109/14767058.2012.739221.
11. Cunningham FG, Lucas MJ, Hankins GD. Pulmonary injury complicating antepartum pyelonephritis. Am J Obstet Gynecol. 1987;156(4):797-807.

12. Galajdova L. Pulmonary dysfunction in acute antepartum pyelonephritis and otherpregnancy infections. JObstet Gynaecol. 2010;30(7):654-8. doi: 10.3109/01443615.2010.501920.

13. Drel IK, Molzhaninov EV, Samsonenko RA. [Effect of hyperbaric oxygenation on catecholamine metabolism in the placenta in late pregnancy toxicosis]. Akush Ginekol (Mosk). 1981;(3):16-29. [Article in Russian].

14. Denisov PI, Proshina IV, Sotnikova EI, Aslanov AG. [Placental scintigraphy--a diagnostic method for evaluating indications for hyperbaric oxygenation in pregnant women with high risk of perinatal pathology]. Akush Ginekol (Mosk). 1989;(9):25-7. [Article in Russian].

15. Davydkin NF, Denisov O, Artyukh YA. [The use of hyperbaric oxygen therapy in treatment of chronic placental insufficiency]. J Restor Med Rehab. 2010;(5):65-67.[Article in Russian].

16. Sparacia B. New Frontiers: $\mathrm{HBO}_{2}$ in Treatment of Fetal Growth Deficiencies. In: Oriani G, Marroni A, Wattel F, editors. Handbook on hyperbaric medicine. New York: Springer; 1996:791-808.

17. Xiao XM, Wang YL, Long Y, Chen X. [The effect of hyperbaric oxygen on late-onset fetal growth restriction]. Chinese J Perinat Med. 2003,6(6):359-362. [Article in Chinese]. 18. Gill AL, Bell CN. Hyperbaric oxygen: its uses, mechanisms of action and outcomes. QJM 2004;97(7):385-95.

19. Boerema I, Meyne NG, Brummelkamp WH, Bouma S, Mensch MH, Kamermans F, Stern Hanf M, van Aalderen. [Life without blood]. Ned Tijdschr Geneeskd. 1960;104:94954. [Article in Dutch].

20. Bitterman H. Bench-to-bedside review: oxygen as a drug. Crit Care. 2009;13(1):205. doi: 10.1186/cc7151.

21. Van Meter KW. The effect of hyperbaric oxygen on severe anemia. Undersea Hyperb Med. 2012;39(5):937-42.

22. Kaide CG, Khandelwal S. Hyperbaric oxygen: applications in infectious disease. Emerg Med Clin North Am. 2008;26(2):571-95, xi. doi: 10.1016/j.emc.2008.01.005. 23. Kolpen M, Mousavi N, Sams T, Bjarnsholt T, Ciofu $\mathrm{O}$, Moser $\mathrm{C}$, et al. Reinforcement of the bactericidal effect of ciprofloxacin on Pseudomonas aeruginosa biofilm by hyperbaric oxygen treatment. Int $\mathrm{J}$ Antimicrob Agents 2016;47(2):163-7. doi: 10.1016/j.ijantimicag.2015.12.005.

24. Kurt T, Vural A, Temiz A, Ozbudak E, Yener AU, Sacar S, Sacar M. Adjunctive hyperbaric oxygen therapy or alone antibiotherapy? Methicillin resistant Staphylococcus aureus mediastinitis in a rat model. Braz J Cardiovasc Surg. 2015 Sep-Oct;30(5):538-43. doi: 10.5935/1678-9741.20150055.

25. Cimsit M, Uzun G, Yildiz S. Hyperbaric oxygen therapy as an anti-infective agent. Expert Rev Anti Infect Ther. 2009 Oct;7(8):1015-26. doi: 10.1586/eri.09.76.

26. Fujita N, Ono M, Tomioka T, Deie M. Effects of hyperbaric oxygen at 1.25 atmospheres absolute with normal air on macrophage number and infiltration during rat skeletal muscle regeneration. PLoS One. 2014;9(12):e115685. doi: 10.1371/journal.pone.0115685.

27. Hopf HW, Holm J. Hyperoxia and infection. Best Pract Res Clin Anaesthesiol. 2008;22(3):553-69.

"Corresponding author: Aleksey A. Lukaev, MD. Mytishchi municipal clinical hospital, Mytishchi, Moscow Region, Russia. E-mail: alekseilukaev@mail.ru 
28. Jain KK. Textbook of Hyperbaric Medicine. Springer International Publishing AG; 2017.

29. Benny M. Effectivity of hyperbaric oxygen therapy on lowering systolic blood pressure and heart rate among naval divers. J Hypertens. September 2016; LBPS 02-5.

30. Lopez-Calderon EM, Guevara-Balcazar G, OsorioAlonso H, Lara-Padilla E, Hong-Chong E, Ramirez-Sanchez I, Castillo-Hernandez MC. Modification of blood pressure and vascular reactivity to angiotensin II in the perfused heart of hypertensive rats treated with hyperbaric oxygenation. Biomedical Research 2017;28(1):145-51.

31. Lindel K. Undersea \& Hyperbaric Medical Society. Hyperbaric Oxygen Therapy Indications (Thirteenth Edition). The Hyperbaric Oxygen Therapy Committee Report 2014. Available from: https://www.uhms.org/resources/hboindications.html

32. Cartlidge PH, Rutter N. Percutaneous oxygen delivery to the premature infant. Lancet. 1988;1(8581):315-7.

33. Roman H, Saint-Hillier S, Dick Harms J, Duquenoy A, Barau G, Verspyck E, Marpeau L. [Gas embolism and hyperbaric oxygen treatment during pregnancy: a case report and a review of the literature]. J Gynecol Obstet Biol Reprod (Paris). 2002;31(7):663-7.[Article in French].

34. Wattel F, Mathieu D, Mathieu-Nolf M. [A 25-year study (1983-2008) of children's health outcomes after hyperbaric oxygen therapy for carbon monoxide poisoning in utero]. Bull Acad Natl Med. 2013;197(3):677-94; discussion 695-7. [Article in French].

35. Orasmuradov AA, Paendi OL, Paendi FA. Modern Possibilities of Hyperbaric Oxygen Therapy in Pregnant Women with Anemia. International Journal of Biomedicine. 2014;4(2):82-84.

36. Baidina SA, Gramenitskiy AB, Rubinchik BA. Manual of hyperbaric medicine. M: Medicine, 2008. [In Russian]. 